\title{
ЭПИДЕМИОЛОГИЯ САХАРНОГО ДИАБЕТА В ПЕРМСКОМ КРАЕ ПО ДАННЫМ ФЕДЕРАЛЬНОГО РЕГИСТРА САХАРНОГО ДИАБЕТА: СТАТУС 2019 ГОДА
}

\author{
Смирнова Е.Н., Аникина Н.В., Тарбеева Н.С.
}

ФГБОУ ВО ПГмУ им. академика Е.А. Вагнера Минздрава России, Пермь

ЦЕЛЬ: оценить эпидемиологическую обстановку по сахарному диабету (СД) среди населения Пермского края за 2019 г., определить тенденции дальнейшего развития.

МАТЕРИАЛЫ И МЕТОДЫ: проведен анализ данных Федерального регистра сахарного диабета за 2019 г. со статистической обработкой показателей.

РЕЗУЛЬтАТЫ: численность населения в Пермском крае на 2019 г. - 2599301 человек. Нарушения углеводного обмена различной степени выраженности среди взрослого населения зарегистрированы в 94721 случаев. Несмотря на многообразие форм СД, основную долю больных составляют лица с СД 2 типа - 84731 случая в сравнении с СД 1 типа - 3786 случаев. Выявляемость гестационного сахарного диабета составила 303 пациентки. Среди детского и подросткового возрастов распространенность СД 1 типа ожидаемо оказалась значимо выше в сравнении с СД 2 типа (761 против 25 случаев). Количество впервые выявленных случаев СД 1 типа среди взрослого населения - 202 человека, СД 2 типа 6675 человек за год. При изучении структуры осложнений среди пациентов с СД 2 типа выявлено, что превалирующим типом явились микрососудистые осложнения (диабетическая ретинопатия - $7381-$ 8,25\%, диабетическая нефропатия - $14186-15,86 \%$, диабетическая нейропатия - $18789-21,0 \%$. Зарегистрированы значимые макрососудистые осложнения: ишемическая болезнь сердца. Стенокардия напряжения - 10396 (11,62\%), инфаркт миокарда - 4663 (5,21\%), острое нарушение мозгового кровообращения - 6832 (7,64\%). Распределение осложнений у пациентов СД 1 типа: диабетическая нейропатия - 1280 (31,77\%), диабетическая нефропатия - 1095 (27,18\%), ДН-1755 (43,56\%), однако представленность вышеперечисленных макрососудистых осложнений была значимо ниже в сравнении с пациентами СД 2 типа и составила 11,07\% случаев. Помимо сердечно-сосудистых катастроф, социально значимым, неблагоприятным последствием СД является синдром диабетической стопы и его инвалидизирующий исход - ампутации нижних конечностей, которые были зарегистрированы СД 2 типа - 680 (0,76\%), СД 1 типа - 56 (1,39\%). Известно, что СД опасен не столько распространенностью, сколько тяжестью его осложнений, приводящих к нарушению трудоспособности и инвалидизации пациентов, снижению качества жизни. У пациентов с различными видами СД всех возрастных групп (94731) утрата трудоспособности зарегистрирована 26847.

Среди взрослого населения - 26375 случаев, среди детей -472.

ВывОды: в Пермском крае заболеваемость СД составляет 3,64\% на все население. Основной вклад в эпидемиологию СД взрослого населения вносит СД 2 типа, у детей и подростков - СД 1 типа. Известно, что учет субклинических форм нарушений углеводного обмена (нарушенная толерантность к глюкозе, гестационный (Д) обеспечивает своевременное лечение и предупреждение перехода в клинически значимые состояния. Несмотря на превалирование микрососудистых осложнений, основной вклад в структуре причин утраты трудоспособности принадлежит нефатальным сердечно-сосудистым событиям и ампутациям конечностей. 